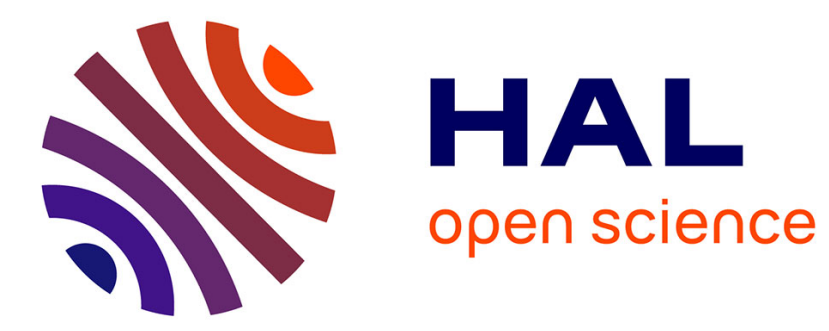

\title{
Innovating in reverse: services and the reverse product cycle
}

Faïz Gallouj

\section{To cite this version:}

Faïz Gallouj. Innovating in reverse: services and the reverse product cycle. European Journal of Innovation Management, 1998, 1 (3), pp.123 - 138. 10.1108/14601069810230207 . halshs-01114103

\section{HAL Id: halshs-01114103 \\ https://shs.hal.science/halshs-01114103}

Submitted on 7 Feb 2015

HAL is a multi-disciplinary open access archive for the deposit and dissemination of scientific research documents, whether they are published or not. The documents may come from teaching and research institutions in France or abroad, or from public or private research centers.
L'archive ouverte pluridisciplinaire HAL, est destinée au dépôt et à la diffusion de documents scientifiques de niveau recherche, publiés ou non, émanant des établissements d'enseignement et de recherche français ou étrangers, des laboratoires publics ou privés. 
GALLOUJ F. (1998), Innovating in reverse: services and the reverse product cycle, European Journal of Innovation Management, Vol. 1, n³, p. 123-138.

Innovating in reverse: Services and the reverse product cycle

Faïz GALLOUJ*

CLERSE, IFRESI, Universiyof Lille I

*Associate professor, PhD
University of Lille I
Faculty of Economics
59655 Villeneuve d'Ascq Cedex
France
Tel : (33) 320125877
Fax : (33) 320125831
Email: faiz.gallouj@ifresi.univ-lille1.fr 


\section{Innovating in reverse: Services and the reverse product cycle ${ }^{1}$}

\section{Summary:}

As they account for the largest share of employment and value added, services do not (or cannot) lie outside a Schumpeterian view of innovation phenomena. Of the various attempts at shedding more light on the mechanisms of innovation in service industries and firms, we consider the "reverse product cycle" to warrant special attention because of its highly thought-provoking nature and its theoretical ambition. This article has two objectives: firstly, to present this interesting and still neglected theoretical study, and secondly, to evaluate on a theoretical and empirical level the extent to which Barras' model meets the objective of a "theory of innovation in services".

Key words : Innovation, service industries, reverse product cycle

\section{INTRODUCTION}

Since they account for the largest share of employment and value added, service industries are at the heart of contemporary economies. From a Schumpeterian perspective, innovation phenomena must be at work in service firms. In an economic sector which is, admittedly, highly heterogeneous, but whose output remains largely "imperceptible", the question, therefore, is what are the specifities of innovation in services?

The different answers given to this question by economic and management literature can be schematically classed into three categories (F. Gallouj, 1994 and C. Gallouj and F. Gallouj, 1996):

- "service-oriented" approaches (Gallouj, 1991 ; Van der Aa and Elfring, 1993; Gadrey et al., 1995; Sundbo, 1993) which emphasise the specificities of innovation in services and show particular innovation modalities in these activities (particularly high frequency of ad hoc innovation, "intangible" service trajectories as opposed to technological trajectories, etc.). In management science, and particularly, service industriesmarketing, these service-oriented approaches towards innovation are defined particularly by the distinction between basic

\footnotetext{
${ }^{1}$ This paper is based upon empirical materials derived from a EU financed project (DG XII, TSER programme) called SI4S (Services in innovation and innovation in services).
} 
services and peripheral services. Viewed from this angle, a new service corresponds to setting up a new basic service, and the extension of an existing service occurs through the addition of a new peripheral service (Flipo, 1984; Eiglier and Langeard, 1987; Jallat, 1992; Lovelock, 1992). The course taken by financial innovation (e.g. Hardouin, 1973; Desai and Low, 1987) represents, at a more subtle level (that of demand for service characteristics), this view of "product/service";

- integrative approaches (Belleflamme, Houard, Michaux, 1986; Barcet, Bonamy, Mayère, 1987; Gallouj and Weinstein, 1997) whose aim is to reconcile goods and services in a single innovation theory. These approaches are based on a functional conception (or one in terms of characteristics) of the product, and they propose typologies of forms of innovation valid for both goods and services;

- technologist approaches, by far the most numerous, which can be summarised as being concerned with the introduction of equipment and technical systems into service firms and industries.

We consider Barras' reverse product cycle model, on which this study is centred, to belong to the last category. We do not intend to examine the first two approaches ${ }^{2}$; it is, however, necessary to justify our particular interest in Barras' model.

Even though it is, as we shall see, fundamentally technologist, this model nevertheless exceeds a simple analysis of the assessment and consequences of adopting technological innovation in services, unlike the majority of the economic and management literature on this theme. Its consideration of innovation processes in services is not, as is often the case in other works, the "by-product" of other analytical priorities. Indeed, this model aims to draw up a study on the production of innovations by services themselves. Consequently, it is an interesting theoretical advance and one which we still feel to be somewhat neglected.

Richard Barras' theoretical objective is clearly set out in the title of one of his reference articles published in the journal Research Policy in 1986: "Towards a Theory of Innovation in Services". The objective of our article is twofold: firstly, to present Barras' theory as it

\footnotetext{
${ }^{2}$ For a survey of the literature on innovation in services, cf. particularly Gallouj (1994), Miles et al (1995), C. Gallouj and F. Gallouj (1996), F. Gallouj (1997).
} 
appears not only in Barras' own article, but also in other earlier and later works; secondly, to evaluate the extent to which the model meets the objective of a "theory of innovation in services", and what needs to be retained from it for our own perception of innovation in services. It can already be said that, in services more than elsewhere, innovation cannot be reduced, as is the case in Barras' theory, to its technological manifestations. The definition of innovation put forward by Schumpeter at the beginning of the century, therefore, through its broadness, remains the best reference ${ }^{3}$.

\section{II. - PRESENTATION OF THE MODEL}

In a series of empirical studies covering the fields of banking, insurance, accounting and local public administration, Barras (1986, 1990), highlights a product life cycle which he describes as the reverse of the cycle at work in manufacturing, where the initial phase, predominantly product innovation, is followed by a second phase, dominated by process innovation (Abernathy and Utterback, 1978).

Following this model, the evolution in services will be the reverse, because the incremental phase of process innovation will be followed by radical phases of process innovation, then of product innovation, the respective purposes of which are improving the efficiency of the service, improving its quality, and conceiving a new service.

The empirical assessment of this reversal of the life cycle is the core of Barras' theory of innovation in services. Each stage of the reverse cycle is initiated by the introduction of a particular technological system: respectively, mainframe computers, minicomputers and microcomputers and networks (cf. table 1).

Unlike some typological approaches (Pavitt, 1984; Lakshmanan, 1987; Soete and Miozzo, 1990), Barras' model does not restrict firms to a given technological trajectory, but considers the nature of the trajectory to vary from one phase of the cycle to another. He thus places the debate on service innovations in a dynamic perspective. This model, the usefulness and

\footnotetext{
${ }^{3}$ Indeed, Schumpeter's definition contains five categories: new goods, new production methods, new markets, new sources of raw materials, new organisation of production.
} 
limitations of which we are examining here, is without doubt the first economic study which explicitly aims to devise a theory of innovation in services in the Schumpeterian tradition.

\subsection{Incremental process innovation and improvement of service efficiency.}

The first stage of the reverse cycle (cf. table 1) is initiated by service-providing firms adopting back-office mainframe computers. The setting up of these mainframe computers is the opportunity for many forms of learning, resulting in incremental improvements in the service provided. These incremental innovations concern the process: they reduce the cost of the service provided without affecting its quality. Examples of these incremental process innovations are the computerisation of insurance policy records, local government personnel records and payroll, audit techniques and internal time recording in accountancy firms.

According to Pavitt's taxonomy (1984), at this stage of the cycle, firms are "technologically dominated by suppliers". This does not, however, mean that no interaction takes place; quite the opposite. Indeed, Barras stresses the idea of an interactive innovation process, which introduces a feedback loop between the incremental process innovation produced by the service provider, and the producer of new technologies. Indeed, incremental process innovations affect not only the technological trajectories in the field of equipment sectors (leading to other innovations in this field: e.g. superior software applications), but also the institutional structure of the service activity and the nature and volume of demand for the service (which costs less).

In terms of impact on production factors, the first stage of the reverse cycle is characterised by technical progress which saves labour and increases the amount of capital used.

\subsection{Radical process innovation and improvement of service quality}

The following phase coincides with the introduction of a new generation of computer systems: mini and microcomputers. These new systems benefit from the knowledge and experience base accumulated during the previous phase, and, in turn, initiate new learning and innovation opportunities which are more centred on the front office and client 
satisfaction. These innovations, however, are of a more radical nature. Their purpose is no longer to lower costs, but to enhance the quality of the service provided. The best known examples of this type of innovation are automatic teller machines, other examples being the computerised management of housing waiting lists in local public administration, on-line insurance policy quotations, and computerised book keeping services in accountancy firms.

With the acceleration of the speed at which technical change in equipment spreads, its impact on production factors changes. Indeed, technical advances have progressively less effect on the labour factor, and, instead, promote the improvement of quantity and, above all, the quality and variety of capital.

\section{3. "Product" innovation}

The purpose of the third phase of the cycle, the product innovation phase, is to open up new markets. It is accompanied by a radical change in the service firm's structure and strategies. The firm becomes freed from subordination to technological suppliers, and can produce its own innovations autonomously, within specialised departments, or by calling upon external service providers, particularly those belonging to knowledge-intensive business services, but where the balance of power is in the service firm's favour.

On the face of it, this phase seems to be the most interesting, as it corresponds to producing new services, rather than simply improving the efficiency or quality of existing services.

However, two limitations of the model are already evident, to which we will return in more detail:

- as it is a technologist vision, it is a restrictive view of "product" innovation, as is borne out by the examples given, such as interactive and fully-automated auditing and accounting processes in accountancy firms, complete on-line services in insurance firms, home banking, and all "home" services made possible by new information and telecommunication technologies.

- moreover, the third phase would barely get under way, and in all cases, its progress would require an informational infrastructure to be set up. 
This "product" innovation phase has a positive effect both on output and employment. It is associated to technical advances which save capital whilst improving its quality.

\section{TAKE IN TABLE 1}

Barras' model, the main points of which we have just presented, suffers from using concepts from the field of manufacturing (product, life cycle). Indeed, it could be said, paradoxically, that "in services, the product is a process". It is therefore difficult to make the distinction between product innovation and process innovation. By the same token, it becomes difficult to follow the "product" life cycle. But other problems, which to our mind are more important, must be resolved if Barras' model is truly to constitute a theory of innovation in services. Indeed, in this model, innovation is not envisaged independently of technological possibilities. It is also a model whose field of application (in terms of fields of activity) merits discussion.

\section{III. - A MODEL WHICH IS LIMITED IN TERMS OF TYPE OF ACTIVITY}

Two factors at the centre of Barras' model lead to its domain of validity being questioned:

- The enabling technologies which we have seen to be at the root of the different stages of the reverse cycle. In the main, these enabling technologies are information and telecommunications technologies. It is worth mentioning the confusion which arises (frequently in studies) between enabling technologies (mainframe computers, mini and microcomputers, networks) and the innovations made possible by these enabling technologies (which can themselves be incorporated into equipment and technical systems (e.g. automatic teller machines (ATMs) and cashpoints)). Indeed, automatic teller machines and cashpoints are not enabling technologies, but radical process innovations whose enabling technologies are particularly networks of dumb terminals.

- The vanguard sectors which, in terms of their contribution to economic growth, are particularly dynamic. Barras would class these as financial and business and professional services, and these served as the empirical field of investigation for his model. 
We would like to raise the following two questions:

- Are there not other enabling technologies, other than information and telecommunications technologies; can the validity of the model therefore not be extended to other technological systems?

- Is the analysis valid for all vanguard services, and can its field of application be extended further than vanguard services?

\subsection{Is Barras' model valid for all vanguard services and beyond?}

Firstly, this question can be considered on the basis of concrete examples.

Legal consultancy to firms has seen a relatively high growth rate in France, which has been encouraged by a number of recent institutional changes. According to Barras' definition, as a "knowledge intensive business service", it belongs to the vanguard services. Does it, however, display a reverse product life cycle? The answer is negative for different reasons: firstly, in France, this activity is currently not particularly open to information technology; the second reason (closely linked to the first) is that it is an activity which does not deal with codified information, but with expertise. This does not, however, prevent it from innovating, although its innovations do not slot neatly into the product innovation/process innovation typology. Indeed, what we see here (and we will come back to this point in section 5.1) are different forms of innovation lying outside Barras' model: ad hoc innovations arising from the need to come up with a new solution to a client's problem; the opening up of new legal fields through accumulation of knowledge and expertise; formalisation innovations through the introduction of methods, and through procedures of combining/dissociating existing services (architectural or recombination innovations).

Another legal profession, that of notary, very rapidly embarked on the road to office computerisation. Microcomputers and fax machines were introduced under the impetus given by professional institutions. Indeed, the information processed by notaries is often more standardised. This innovation does not, however, seem to have followed Barras' reverse 
cycle. Admittedly, incremental process innovations occurred, but no radical process innovations or, indeed, product innovations. Obviously, in both cases, the strength of institutional rigidities must be pointed out, as must the degree of complexity and instability of the environment and of the problems to be solved.

Our conclusion, therefore, is that Barras' model applies mainly to those vanguard services and other services which are most affected by technological evolution, and that it cannot be applied to most other cases. It does cover some (but, as we shall see, not all) innovation modalities in "pre-industrial" services, i.e. essentially mass informational services (banks, insurance, public administration, large audit firms).

Other assessments of Barras' model's field of validity draw similar conclusions. Some service marketing specialists (E. Langeard and P. Eiglier, 1990) consider Barras' model to be valid only for services with a substantial back office (insurance, banking), as it is dominated by back-office technologies. It is not valid for services where the service relationship (« servuction ») occupies a central position, as is the case in consultancy and most knowledge intensive business services. Economists interested in Solow's paradox (Petit, 1990), consider the model's main field of validity to be household services, since they have a strong element of self-service.

An additional question, which we will only touch upon here, is whether, from the perspective of a functional approach, Barras' thesis could be extended to service functions internal to firms, particularly when the latter adopt, as is often the case, informational technologies.

\subsection{Can Barras' model be applied further than informational technologies?}

The informational paradigm on which Barras' model is based is certainly dominant in our economies, but other technological systems also occupy an important place in them, sometimes by merging with the previous paradigm. This is the case with technologies involved not only in storing, processing and circulating information, but also in material logistics, i.e. storing, handling and circulating materials (transport, refrigeration, cooking and cleaning technologies etc.). It is also the case with new technologies such as medical instrumentation, genetics and biotechnology, etc. 
Before Barras' model could be applied to technologies other than informational technologies, it would have to be verified that the adoption of these technologies initiates a reverse cycle whose initial phases are dominated by process innovation, before the following phases of "quasi-product" innovation occur. There are indicators that such an evolution occurs.

1) There appear to be good examples of new "service-products", new "formulas" or "concepts" in activities that utilize material transformation and logistics technologies, in distribution, for instance, or in restaurant chains (Pizza Hut, the french "Courte-Paille" or Spizza $\left.30^{\prime} . ..\right)$. The automation of petrol pumps in service stations, for instance, may be considered a radical process innovation similar to automatic teller machines. Moreover, the opening of sales points in these service stations, using all the techniques of the supermarket and open permanently, is related to 'product' innovation in the sense used by Barras.

2) Moreover, situations can be envisaged in which the Barras cycle is based on a combinatorial adoption of information technologies and material transformation and logistics technologies. This is the case with firms like Federal Express, Chronopost and mail order companies.

An example is containerized transport. While this technology is relatively old (Ernst, 1985), it has been a source of process innovations in Barras' sense; in the first place it improved the efficiency of transport without changing the nature of the service itself. The later standardization of container sizes and development of technologies involving the unloading cranes and their standardization have been factors in improving service quality in terms of a greater availability and so on (radical process innovation). With the introduction in recent years of information and telecommunications technologies into maritime container transport, the quality of the service has been improved so much that it is possible to speak of a "new service" in Barras' sense ${ }^{4}$.

Another example is fast food in the United States. In certain fast food restaurants, cooking and refrigeration technologies are permitting incremental process innovations (affecting the

\footnotetext{
${ }^{4}$ It is now possible to know at every moment to whom each container belongs, what it contains, where it is located, where it comes from and where it is going, where it should (optimally) go once empty, what kind of container it is, if it needs to be repaired and at what price, etc. (Ernst, 1985).
} 
"back-office": the central kitchen). On the other hand, computerized menu ordering systems can be seen as radical process innovations (by analogy with the automatic teller machines of banks, which are considered so by R. Barras).

But even then, supposing that Barras' model could have a wider field of application than the informational technologies, the fact remains that it would not necessarily accommodate all the diverse forms of innovation in service firms and industries.

\section{IV. - A MODEL DETERMINED BY TECHNOLOGY}

Barras' model's main limitation is that it reduces the degree of variety of innovation in services, which is paradoxical on two counts:

- firstly, Barras claims to follow Schumpeter, but Schumpeter's definition of innovation is, in fact, broad and open, and can accommodate intangible "products" and "processes".

- secondly, the technological bias of the analysis means that recent important advances made in theories of financial and commercial innovation are not taken into account. We will indicate several important points of these advances here.

Analyses of financial innovation based on the demand for certain characteristics have developed independently with a view to providing a theory that applies solely to financial services. They take account of facets of innovation which are not accommodated by Barras' model. The basic hypothesis is that any financial product can be broken down into a certain number of service characteristics by which it is defined. From this point of view, any change in the topography of these characteristics, whether this involves the emergence of new characteristics or of new combinations of existing characteristics, constitutes an innovation.

Hardouin (1973) formalises this analysis as follows. A monetary and financial instrument Ti can be defined a priori or a posteriori by a finite set of " $n$ " characteristics and can therefore be written in the form of a vector with $\mathrm{n}$ dimensions in which the tij indicate the extent to which property $\mathrm{j}$ is incorporated in instrument $\mathrm{i} . \mathrm{Ti}=\left(\mathrm{t}_{\mathrm{i} 1} \ldots . . \mathrm{t}_{\mathrm{ij}} \ldots . . \mathrm{t}_{\mathrm{in}}\right)$. Thus if the instrument $\mathrm{Ti}$ does 
not have property $\mathrm{j}, \mathrm{t}_{\mathrm{ij}}=0$. Innovation appears in the following two cases: a variation in $\mathrm{t}_{\mathrm{ij}}$, i.e. a variation in the extent to which the existing property $\mathrm{j}$ is incorporated in the instrument (e.g. the instrument is more liquid), and the activation of a property that did not previously exist (transition from $\mathrm{t}_{\mathrm{ij}}=0$ to $\mathrm{t}_{\mathrm{ij}} \neq 0$ ).

For example assuming that any financial service, from the simplest to the most complex, can be represented by a given combination of the following three functions or characteristics (Niehans, 1983) : the exchange of current money against future money, the linking of borrowers and lenders, the making of payments in the name of a client, this author defines innovation as any new way of combining these three aspects.

Niehans also introduces an interesting distinction between irreversible combinations (innovations), which he describes as "technological" but which are not limited to material technologies since they include double-entry book-keeping, which was invented at the end of the Middle Ages, and those that are more reversible and cyclical, which he terms "adaptive innovations". Innovations in this latter category disappear as soon as the conditions that encouraged their development have themselves disappeared.

Like specialists in the financial services industry, students of retailing have sought to develop theoriesof innovation adapted to their particular field.

The most important of them relate to the dynamic of shop formats, which are conceived of in terms of life cycle. Thus the "wheel of retailing" model (McNair, 1958) can be summarised as follows:

1) All new forms of retailing appear first in a "discount" version, i.e. outlets offer a limited range of goods and services and the main objective is to maximise sales volumes.

2) Their success causes the "wheel" to revolve as retailers gradually "trade up" by adding new products and services to the original ranges; this leads in turn to increased operating costs and higher prices. 
3) This "bourgeoisification" of the retail form opens up the market for new, more "Spartan" entrants (to borrow the terms used by Tarondeau and Xardel, 1992).

Other analyses couched in terms of cycles, which cannot be outlined in any detail here (cf. C. Gallouj, 1997), have extended the "wheel of retailing" model:

- Goldman's analyses (Goldman, 1975) distinguish between various possible forms of "trading up" or ways of causing the wheel to revolve by the degree of innovation in goods or service they introduce into the range;

- in the "accordion theory" (Hollander, 1966) the retailing dynamic is characterised by alternation between outlets offering a wide, non-specialist range of products and those with a narrow, specialised product range.

However, the cycle model in its various forms, as well as Barras' reversed cycle model, cannot account adequately for the wide diversity of forms of innovation in the retail sector. These retail cycle models are concerned only with innovation in shop format (i.e. organisational innovation). However, even in this particular case, they are trapped within a binary logic (low/high prices; wide/restricted product range) and fail to take full account of the diversity of new shop formats and of new forms and new channels of distribution.

Nor do these models take account of the following forms or areas of innovation, most of which require detailed investigation if they are to yield up their secrets:

- new methods of selling (mail order, door-to-door selling ...);

- new products and services retailed in stores;

- new processes (or new forms of organisation and operation) within the same format, whether based on the introduction of new technologies or not (within the same form of retail outlet or within the environment - customers, suppliers, other stores - of the form under consideration).

Contrary to financial innovation theories and commercial innovation theories, in Barras' model, innovation does not exist outside of technological possibilities. This is true not only of process innovations, but also of so-called "product" innovations, occurring in the third 
phase of the cycle. In the following section, we will attempt to illustrate, through concrete examples, the diverse forms which innovation in services can take.

\section{V. - BARRAS' MODEL PUT TO THE TEST: CONSULTANCY, TRANSPORT AND INSURANCE}

Despite his affiliation to Schumpeter, we have seen that Barras adopts a reductionist view of "new services" (new "products"). The object of this section is to illustrate the multiplicity of innovation forms and trajectories in the three service industries, which display differing relationships with materiality and technology:

- consultancy (the very epitome of a "pure" service)

- road haulage (the tangible dimensions of which are obvious),

- but, above all, insurance and financial services (which are situated somewhere between the other two service industries in terms of their relationship with materiality and technical systems, and which are one of Barras' main fields of investigation).

\subsection{Consultancy}

Consultancy activities have much in common with research activities: their high content of "grey matter", a similar purpose, namely "solving problems", etc. However, paradoxically, it is difficult to study and evaluate innovation activities in this field using traditional analytical tools. Some researchers are quick to conclude that little or no innovation takes place in this type of activity, apart from, at the very most, the technical systems adopted. Consultants themselves are often split into two camps: those who underestimate their capacity for innovation and those who consider every service transaction to be an innovation, as each transaction is new and original. For our part, we do not share either of these conclusions, which prove how unfit our analytical tools are for understanding the nature of innovation in service firms. The difficulty stems in particular from the intangible and interactive nature of this type of activity. These characteristics also call into question the traditional distinction between product innovation and process innovation (C. and F. Gallouj, 1996; Gallouj and Weinstein, 1997). Innovation does exist in this type of activity, but it can take different forms. Our empirical investigations allow three different types of innovation to be envisaged, 
which we will designate by the following terms: ad hoc innovation, anticipatory innovation (or new expertise field innovation) and formalisation innovation.

\section{Ad hoc innovation}

Ad hoc innovation is the conception of a new solution to a client's problem (which is, itself, often completely novel), with the client's participation. It can be a solution to an organisational, strategic, legal, fiscal, social, or human problem, etc. To ensure that the ad hoc innovation can, to a certain extent, be reproduced, and to establish a boundary between ad hoc innovation and the ad hoc nature of all consultancy service transactions, it is necessary for the service provider, at the outset of the service and innovation, to embark upon a process of formalisation, i.e. codification of certain elements of the service, which can then be reused elsewhere, and which will help enrich the organisational memory of the firm.

This is the interface which constitutes the "laboratory" where this "non-programmed" (Zaltman et al., 1973) and somewhat emergent form of innovation is conceived.

Consequently, the probability of an ad hoc innovation occurring, and the quality and nature of the innovation, depend heavily on the nature and quality of the interface.

Apart from the service provider's own intrinsic elements, the "quality" of the interface depends on:

- the quality of the experts from the client organisation who are involved in the interface. Indeed, these professionals partly determine how well the request is formulated and the "true need" (which often differs from the request) is (re)built (Gallouj, 1994). Furthermore, the success of the innovative solution and its assimilation by the firm depends on their ability to absorb the new ideas.

- the quality of the problem raised. Original and unprecedented problems are potential sources of ad hoc innovation. That said, the innovation potential arising from curative and preventative problems (according to Kubr's terminology, 1988) must not be underestimated. Moreover, strategic problems are often more fruitful sources of innovation than more 
operational or routine problems. These strategic problems are most often the subject of sparring-type interfaces (cf. Gadrey and Gallouj, 1998). They are rarely contracted out. The terms of the analysis can thus be reversed, concluding that sparring type interfaces are more frequent sources of innovation than jobbing- type interfaces.

On a qualitative level, it can be said that opportunities for ad hoc innovation seem to increase with the size of the service provider and their client. Indeed, the multiplication of "contact" zones, (i.e. interfaces) provides multiple opportunities for reciprocal learning and possibly ad hoc innovation.

The existence of this interface raises two important problems:

- In particular, it is partly responsible for limiting the extent to which the ad hoc innovation can be reproduced in its current form. In our opinion, this is what leads a number of researchers to refuse to class this particular form of mobilising expertise as an innovation. However, knowledge, experience (codifiable or not), tacit and idiosyncratic techniques stemming from practical experience, and methods used for their production and transfer can, for their part, be reproduced.

- It poses serious problems of protection and appropriation. Indeed, as the ad hoc innovation stems from the interface, during a process of reciprocal learning, and as it has a strong tacit and contextual dimension, it is difficult to designate its inventor or owner. It is impossible, if the need arises, to ensure protection.

\section{Anticipatory innovation(or new expertise field innovation)}

This particular form of innovation could also be called a "new field of knowledge and/or expertise". It can be considered as a particular manifestation (i.e. adapted to knowledgeintensive business services), of what Barcet, Monamy and Mayère (1987) call functional innovation (the appearance of a new function). The ideas at the root of such an innovation can stem from the interface (i.e. direct exchanges with the client, the expression of the client's needs), but they more generally stem from what we call the "abstract need", (i.e. the "diffuse" background noise emitted by the environment), which is complex and unclear, and 
not linked to any particular client (Gallouj, 1994). As the environment and the client's needs are monitored and listened to, new needs emerge, which must be satisfied. Anticipatory innovation consists of collecting and accumulating new knowledge and expertise relevant to the "problem" or anticipated need, stemming from technological, economic, social or institutional change. Faced with particularly novel problems, i.e. problems for which there is little available expertise, the consultant will have to turn to outside experience, to similar situations. He may, in some cases, carry out research which creates genuinely new expertise. In this way, I.T. has given rise to experts in I.T. consultancy and I.T. law, etc., and ecological and environmental concerns, European construction and the opening up of Eastern countries have given rise to many "new fields of expertise", shared by different types of service providers according to their main field of activity (technical, commercial, legal, political, etc.). These new fields of expertise, which have constituted innovations for those who anticipated these changes, are the equivalent of "product" innovations in the field of knowledge-intensive services. However, until an interface has been established with the client, anticipatory innovation will remain potential. Consequently, this presupposes some marketing and communication efforts which, in the field of consultancy, usually take the form of publications, participation in conferences, etc.

As a "new field of expertise", this form of innovation is particularly difficult to protect. Its appropriation can sometimes be facilitated by the realisation of another form of innovation: formalisation innovation.

\section{Formalisation innovation}

Formalisation innovation consists of "putting order" into service functions, which are often vague and unformatted. They must be given form, specified and made concrete. This does not, however, mean that the desired "materiality" necessarily has to be tangible.

These objectives can be met by introducing "boundaries", reference points into the "vague" service. The components of this genuine service framework can be tangible (back-office or interface technical systems, software, etc.) or intangible: methods that constitute the scripts for the "live performance" that services are, organisations embodying service innovations, toolboxes, etc. 
In service activities, this "ordering" of service characteristics and functions is very often the preliminary to implementing mechanisms for architectural- or combinatory-type innovations, which consist of producing new services by combining existing services or, conversely, by dissociating an existing service.

In many services, formalisation innovation constitutes a truly "natural trajectory" in the sense of the evolutionary theory of innovation. That said, we cannot, in the case of professional services, talk of industrialisation.

These three forms of innovation can appear autonomously, or they can be combined and interact. Anticipatory innovation is the central element of this system of interaction, in that it is very often followed by ad hoc and/or formalisation innovations. It must not, however, be reduced to a single particular strategy, a stage in a process whose purpose is one of the other two forms of innovation. Indeed, in consultancy activities, it is just as often an autonomous and viable form of innovation. It is a particular form (one adapted to knowledge-intensive business services) of functional innovation, in the sense of Barcet, Bonamy and Mayère (1987). Anticipatory innovation and formalisation innovation can overlap, as is the case when a new field of expertise is detected and exploited at the same time as methods and tools are developed and autonomous services within the new field of expertise are differentiated. Moreover, ad hoc innovations can be a source of ideas both for improving methods (formalisation innovation) and for new fields of expertise to be detected (anticipatory innovation).

\subsection{Transport.}

It is unlikely that Barras' reverse cycle model can explain the dynamic of innovation in road haulage. Indeed, as we have already stressed, the model applies, above all, to activities whose most important element is the informational element.

Transport can be broken down into three types of operation (as per Gadrey, 1991; Djellal, 1998): 
- those which consist of "handling" tangible objects, i.e. changing, moving or maintaining them (material logistics and transformation operations);

- those which consist of "processing" codified information, i.e. producing, capturing, circulating it, etc. (informational logistics operations);

- those whose main medium is the client and which consists of a direct (contact) service. This third type of operation can apply to transport firms which provide "tour operator" services i.e. whose main operations are immaterial logistics operations, such as organising the flow of information between firms, monitoring and commitment to the client (quality, trust, guarantee) and, more generally, social innovations.

In transport, initially, the material logistic element was dominant (Djellal, 1998), so the activity naturally evolved according to the trajectory of logistical technologies (transport equipment and the handling of materials). These technologies do not seem to have behaved in exactly the same way as mainframe-based computer systems, which are described by Barras in the first stages of development of the (reverse) life cycle of financial, and, more generally, informational services.

However, if back-office mainframe systems have played no role whatsoever in the development of the transport activity, the same cannot be said of decentralised computer systems. It would seem that transport can be considered as an activity involved not only in handling materials, but also in processing information, and even in processing knowledge and the service relationship.

Transport is therefore an activity where several technological and innovation trajectories connect:

- A material logistics technological trajectory (improvement of vehicles and materialhandling systems).

- An informational and communicational technological trajectory (computer systems, telecommunications).

- An immaterial logistical trajectory (organisational knowledge and expertise, service relation, etc.). 
To these three trajectories must be added an organisational or "infrastructural" trajectory (the setting up of computerised roadside information points), which depends mainly on the public authorities.

The first three trajectories can occur independently, when they characterise firms evolving according to only one of the trajectories (specialised trajectory). But most of the time, they connect and merge, becoming inseparable. This is particularly the case with material logistics technological trajectories and informational technological trajectories.

Moreover, as we saw above, the evolution of the transport activity is characterised by two movements:

- enrichment of each of the trajectories, i.e. innovation within each of the functional components of the activity.

- movement from one trajectory to the other.

Whether they are of a logistical or informational nature, technologies are not the only dimensions of innovation in transport. There is also room for truly intangible services ("tour operator"-type services, set-ups of transport and logistical consultancy firms).

\subsection{Insurance}

In this domain, our field studies ${ }^{5}$ highlight the importance of "product/service" forms of innovation, which are absent from the reverse cycle model. It even seems that in some situations, if computerisation brings about process innovations (in accordance with Barras' model), the conception of new "product/services" such as life insurance, damage/injury insurance or assistance policies quite often entails innovative changes in computer systems. A point which Barras' model, however, does not cover.

Innovation in insurance companies and banks may take four generic forms (Gadrey, Gallouj, 1994), which are summarised in the following table. In order to facilitate analysis, these various forms of innovation are presented here separately. In reality, of course, they are

\footnotetext{
${ }^{5}$ They were carried out together with Jean Gadrey. This section is indebted to him.
} 
frequently indissociable from each other, both in the way they are produced and in the effects they have. Thus many process and product innovations are simply two facets of the same phenomenon, and process and organisational innovations are often indissociable from each other. Furthermore, as Y. Lasfargue (1995) rightly points out, the effects of different innovations on the firm, its specialities, skills and jobs, etc., cannot be isolated, but must be systematically comprehended.

\section{TAKE IN TABLE 2}

\subsubsection{Product/service innovations (type A)}

It is a new service, a new "formula", a new concept, a new policy which we ambiguously tend to call a new "product". This is a service (a formula) of contractually making available methods and competencies for managing clients' insurance problems under conditions which are novel.

The characteristic of newness must be assessed form the point of view of the user, i.e. the client. Thus, if the clients obtain the same results or guarantees, the same benefits, but the processes differ, then it is the same "product/service" (and therefore a D-type innovation). Furthermore, if "product/service" innovations can fit the existing management system, the latter often needs to be modified, sometimes innovatively. The "product/service" innovation is then accompanied by a D1-type innovation and Barras' reverse cycle is reversed, as the product innovation (which, admittedly, is not used here in Barras' sense) precedes the process innovation.

This category partly covers what Y. Lasfargue (1995) calls "product, service and mission innovation". Unlike that innovation, however, it excludes innovations such as new distribution channels, which belong to category D3 (front-office innovations).

Product/service innovations may be "absolute" (A1) or "relative" (A2), depending on whether the products or services involved are new to the market as a whole or just to the insurance company concerned. This latter case (imitation) is obviously more frequent than the former, particularly since product/service innovations in the insurance industry are not patentable. Nevertheless, it should be noted that the particular structural characteristics of a 
company (in terms of technologies, distribution channels, etc.) will very often endow the imitation with a certain degree of originality.

Product/service innovations can be tailor-made (A3) to suit a particular kind of risk or client. This is especially the case in group life insurance, the covering of major industrial risks and certain aspects of assistance or support services (e.g. Europ Assistance). However, a distinction must be made between three different kinds of tailor-made innovations. Adaptive tailor-made innovations adjust an existing policy to a given clientele by modifying the premiums or introducing additional clauses. This form of innovation is relatively common, particularly in the SME market. Fully tailor-made innovations are common in the insuring of risks faced by large firms, and involve the drafting of a genuinely specific policy for each client. Finally, special risk policies provide cover for risks for which there are no actuarial statistics available since they affect only very small populations.

To conclude this section on product/service innovations (type A), several subtle differences can be brought into the description. The distinction between radical product/service innovations, relative product/service innovations and tailor-made product innovations may be difficult. A new product does not intrinsically belong to one particular category, but can belong to one or another according to circumstances.

- Thus, an A3-type innovation (tailor-made) can become an A2-type innovation because of changes in regulations. Today, for example, insurance against computer fraud is a tailor-made product usually offered to large firms. If, tomorrow, a change in regulations made it compulsory, it could become a genuine mass product.

- Similarly, tailor-made products developed in the context of brokerage relationships can be distributed by general agents, and reciprocally, products designed for the latter (by technical departments, etc.) can be offered to brokers, in return for, if need be, a "tailor-made" adaptation process.

- A1 (absolute innovation) and A3 (tailor-made innovation) are not necessarily in opposition. For example, the specific contract drawn up for Harley Davidson could be said to be an absolute product/service innovation (A1) since the competitors do not have such a contract; a relative product/service innovation since Harley Davidsons are motorcycles, and there are long-standing motorcycle contracts; a tailor-made innovation (A3) in the sense that it addresses a particular target, for which it adapts a specific product. Similarly, certain innovations, which can be classed as tailor-made (A3) in the sense that they address a large 
firm which has a monopoly over a given activity, can also, given their originality, be radical innovations. The absolute/relative innovation distinction, however, will be reserved only for "general public" "product/service" innovations.

\subsubsection{Architectural innovations (type B)}

This is a frequent form of innovation in services, and has been highlighted by Albert Bressand and Kalypso Nicolaïdis (1988). It must also be noted that this form of innovation is becoming more and more important in manufacturing (particularly in electronic and biotechnology industries). It is thus at the centre of an innovation model entitled "recombination model" (Foray, 1993), or architectural innovation model (Henderson and Clark, 1990). This model contrasts with the radical innovation model (which is governed by the principle of "absolute originality") and with the incremental innovation model (governed by the principle of "first improvement", which preserves the main characteristics of the product, but replaces some secondary characteristics with new characteristics). The recombination model can be defined in the following terms (Foray, 1993): 1) it maintains all the known characteristics of a product; 2) it recombines these different characteristics; 3) it encourages systematically reusing "components"; 4) it may add a slight difference.

Architectural innovation can be divided into two different types according to the following processes:

- the bundling or integration of services, consisting of offering formulas or contracts in which the service provider commits itself to treat a bundle of problems or operations on behalf of the client which were previously dealt with by separate formulas or contracts (type B1);

- inversely, the separation of services by isolating a type of service or a sub-set of operations which previously formed part of an integrated service, offering it as a new service sold separately or as an option (type B2).

Individual elements such as guarantees, options and premiums may be recombined or detached from existing products. Such innovations may also involve changes in the mix of services offered (this is the case in assistance/support policies).

\subsubsection{Innovations based on modifications to the product/service (type C)}


In this case the core of the service, as seen from the client's perspective, is unchanged, which is most often revealed in the fact that its "denomination" remains the same. At the same time, modifications are explicitly introduced into the formulas and the contracts.

The main difference between this type of innovation and the tailor-made innovations referred to above is that innovations based on modifications are supply-driven, whereas tailor-made solutions are demand-driven.

In conclusion, it must be remembered that, in the case of the insurance industry, the traditional notion of product innovation covers a wider reality than is usually imagined. Not only does it correspond to categories A, B and C, but, moreover, some of these can be split into subcategories which themselves are pertinent.

\subsubsection{Process and organisational innovations, innovations in methods and management} (type D)

This generic category can be divided into four subcategories:

- (Process and organisational) innovations associated with product/service innovations (type D1)

In the insurance industry, product/service innovations, whether architectural in nature or based on modifications of existing products/services, almost always require changes in processes and organisation, some of which may be innovative.

It is partly for this reason that it is generally considered difficult, in services, to distinguish between "product innovation" and "process innovation". Barras' theory is obviously reversed here, as it is the conception of a new "product" which leads to computer systems being modified.

This innovation is sometimes entrusted to external service providers, such as IT service companies or manufacturers of transmission and monitoring equipment in the case of assistance/support services. 
-(Process and organisational) innovations associated with a product/service that remains unchanged in terms of both formal specifications and mode of delivery (unchanged quality criteria) (type D2)

This is what Barras calls an "incremental innovation process". In his view, it equates to the first phase of the "reverse product cycle" that illustrates the dynamic of innovation in services. It improves the efficiency of an existing service (i.e. reduces the cost of providing it) without affecting its quality. There is a significant (non-incremental) change in the process (new technologies, new work organisation) while the final service remains unchanged. This category is a back-office innovation.

- (Process and organisational) innovations associated with a product/service whose formal specifications remain unchanged but whose mode of delivery, perceived quality and marketing are to be improved (type D3).

Innovations of this kind involve a significant change in the process (technology, work organisation) while leaving the final product unchanged in formal terms but improved in quality. They affect the front office, i.e. they improve the quality of relationships with customers. Examples: improvements in advice and information; reduction in payment or response times; reduction in waiting times at counters.

- Innovations in management (type D4)

This category includes innovations relating to financial, actuarial, legal and HR management and, in particular, certain innovations in financial management. For example, assets-liabilities model, innovations in risk analysis methods, particularly relating to technical risks in the industrial sphere; legal innovations as applied to insurance, such as the setting up of bancassurance policies; innovations in HRM. We will also include in this category another form of innovation that might be described as informal management or makeshift innovation, in which solutions are found for certain local problems, sometimes in a secretive (even, paradoxically, disreputable) way, particularly when the innovation involves bypassing central computer systems. 
To conclude this point, we can say that:

1) Most of the process innovations taken into account by Barras' model belong to categories D2 and D3;

2) "Product" innovations in the sense of new contracts and new services (categories A, B, C) which are the core of insurance activity are mostly not accommodated by Barras' model, which contains a very restrictive definition of "new products";

3) "Product" innovations (in the sense of new contracts, new services) can give rise to process innovations. In this case, Barras' cycle is reversed in that product innovation precedes process innovation (a return to the traditional cycle).

\section{CONCLUSION}

Barras' model constitutes, in our opinion, a neo-Schumpeterian theoretical synthesis of many studies in terms of "the impact of information technology and telecommunications technology on services". Scattered materials, empirical and theoretical results have been drawn together into a synthetic and dynamic model, with its own internal coherence. Consequently, R. Barras has effectively succeeded in what he set out to do, i.e. devise a "theory of innovation". But it is less a theory of innovation in services than a theory of the spread of technological innovation from manufacturing to services. In other words, the reverse product cycle model remains fundamentally technologist: innovation is not really considered to occur outside of "technological possibilities". It does not take into account, for example, the appearance of new functions which are independent of technology.

Part of the problem stems from the fact that R. Barras does not alter the conceptual frame of reference. The model is, indeed, concerned primarily with material technologies, and no other form of technology is taken into consideration. This bias is doubtlessly due to the choice of technology-intensive service industries as a field of investigation. Product and process innovations are then considered, but the question of the validity of transposing these concepts onto services is not addressed. Finally, the notion of life cycle, reversed or not, also merits the same investigation as regards its true scope in services. 
Once again, this does not mean that Barras' model should be rejected. Indeed, his model studies, in a highly thought-provoking and unprecedented fashion, a certain (important) aspect of innovation in services. Rather than rejecting the model, we must seek to complement the model through studies which place emphasis on the least technologist aspects of this type of innovation. 


\section{BIBLIOGRAPHIE}

Abernathy, W. Utterback, J. (1978), Patterns of Industrial Innovation, Technology Review, 80, June-July, pp. 41-47.

Barcet, A., Bonamy, J. and Mayère A. (1987), Modernisation et innovation dans les services aux entreprises (Modernisation and innovation in business services), Report for Commissariat Général du Plan.

Barras, R. (1986), Towards a Theory of Innovation in Services, Research Policy, 15, pp. 161173.

Barras, R. (1990), Interactive Innovation in Financial and Business Services : The Vanguard of the Service Revolution, Research Policy, 19, pp. 215-237.

Belleflamme, C., Houard, J., Michaux, B. and Ruyssen, O. (1986), Innovation and Research and Development Process Analysis in Service Activities, IRES, Report for EC, FAST programme.

Bressand, A. and Nicolaïdis, K. (1988), Les services au coeur de l'économie relationnelle, Revue d'Economie Industrielle (Services in the heart of the relational economy), 43, pp. 141-163.

Desai, M. and Low, W. (1987), Measuring the Opportunity for Product Innovation, in M. De Cecco (Ed), Changing Money : Financial Innovation in Developed Countries, Basil Blackwell.

Djellal, F. (1998), Innovation in French road haulage, preleminary report for EC, DG XII, TSER programme.

Eiglier, P. and Langeard, E. (1987), Servuction : le marketing des services (Servuction : services marketing), Mc Graw-Hill.

Ernst, M.L. (1985), Electronics in Commerce, in T. Forester (Ed.), The Information Technology Revolution, MIT Press.

Flipo, J.-P. (1984), Le management des entreprises de service (Service firms management), Les Editions d'organisation.

Foray, D. (1993), Modernisation des entreprises, coopération industrielle inter et intrafirmes et ressources humaines (Firms modernisation,inter and intra-firm cooperation and human resources), report for the french Ministery of research and technology, june.

Gadrey, J. (1991), Le service n'est pas un produit : quelques implications pour l'analyse économique et pour la gestion (The service is not a product : some consequences for economic analysis and management), Politiques et Management Public, volume 9, $\mathrm{n}^{\circ} 1$, march.

Gadrey, J. and Gallouj, F. (1994), L'innovation dans l'assurance : le cas de l'UAP (Innovation in insurance : the case of $U A P$ ), report for UAP and the french Ministery of research, University of Lille I, september.

Gadrey, J. and Gallouj, F. (1998), The provider-customer interface in business and professional services, The service industries Journal, Vol. 18, n², April, pp.1-15.

Gadrey, J., Gallouj, F. and Weinstein, O. (1995), New modes of innovation : how services benefit industry, International Journal of Service Industry Management, volume $6, \mathrm{n}^{\circ}$ 3, pp. 4-16.

Gallouj, C. (1997) Innovation in french retailing, preleminary report for EC, DG XII, TSER program, march.

Gallouj, C. and Gallouj, F. (1996), L'innovation dans les services (Innovation in services), Editions Economica, Paris. 
Gallouj, F. (1994), Economie de l'innovation dans les services (Economics of innovation in services), Editions L'Harmattan, Logique économique, Paris.

Gallouj, F. (1997), Towards a Neoschumpeterian Theory of innovation in Services, Science and Public Policy, Vol. 24, $\mathrm{n}^{\circ}$ 6, december, pp. 405-420.

Gallouj, F. and Weinstein, O. (1997), Innovation in services, Research Policy, 26, p. $537-$ 566.

Goldman, A. (1975), The role of Trading up in the development of retail system, Journal of Marketing, Volume 39, n¹, pp. 54-62.

Hardouin, J.C. (1973), L'apparition de l'innovation financière. Contribution à l'étude de ses éléments explicatifs (The appearance of financial innovation : a contribution to the analysis of its determinants), Complementary Thesis, University of Rennes.

Henderson, R.M. and Clark, K.B. (1990), Architectural Innovation : The Reconfiguration of Existing Product Technologies and the Failure of Established Firms, Administrative Science Quarterly, Vol. 35, nำ march, pp. 9-30.

Hollander, S.C. (1966), Notes on the Retail Acordion, Journal of Retailing, Vol. 42, ${ }^{\circ}$ 2, pp. 24-33.

Jallat, F. (1992), Le management de l'innovation dans les entreprises de services au particulier : concepts, processus et performances(Innovation management in household services : concepts, processes and efficency), $\mathrm{PhD}$ Thesis, University of AixMarseille III.

Kubr, M. (1988), Management Consulting : a Guide to the Profession, ILO, Geneva.

Lakshmanan T. (1987), Technological and Institutional Innovation in the Service Sector, Conference "R-D, industrial change and economic policy", University of Karlstad, Sweden, June.

Langeard, E. and Eiglier, P. (1990), L'innovation de service (Service innovation), Working paper, University of Aix-Marseille III, march.

Lasfargue, Y. (1995), Quelques réflexions sur les innovations et l'évolution des métiers (Some thoughts about innovations and jobs evolution), INTEPF seminar "Compétitivité des services : quel avenir pour le travail et l'emploi? (Services competitiveness : what kind of future for work and employment?", Marcy l'Etoile, November 16.

Lovelock, C. (1992), A Basic Toolkit for Service Managers, in C. Lovelock (ed), Managing Services : Marketing, Operations, and Human resources, Prentice-Hall International Editions.

Mc Nair, M.P. (1958), Significant trends and developments in the post war period, in A.B. Smith (ed.) Competitive Distribution in a Free High Level Economy and its implication for the University, University of Pittsburgh Press, Pittsburg, pp. 1-25.

Miles, I., Kastrinos, N., Flanagan, K., Bilderbeek, R., Den Hertog, P., Huntik, W. and Bouman M. (1995), Knowledge-Intensive Business Services : Users, Carriers and Sources of Innovation, Report for DG13 SPRINT-EIMS, march.

Niehans, J. (1983) "Financial Innovation, Multinational Banking, and Monetary Policy", Journal of Banking and Finance, 7, pp. 537-551.

Pavitt, K. (1984), Sectoral Patterns of Technical Change : Towards a Taxonomy and a Theory, Research Policy, 13, pp. 343-373.

Petit, P. (1990), Emploi, Productivité et technologies de l'information : le cas des services (Employment, productivity and information technologies : the case of service industries), IRIS Conference, University of Paris XI Dauphine "Competence and competitiveness", april, 5.

Soete, L. and Miozzo, M. (1990), Trade and Development in Services : a Technological Perspective, MERIT, The Netherlands. 
Sundbo, J. (1993), Innovative Networks, Technological and Public Knowledge Support Systems in Services, Roskilde University, mimeo.

Tarondeau, J.C. and Xardel D. (1992), La distribution, (Retailing), Paris, PUF, Que sais-je.

Van Der Aa, W. and Elfring, T. (1993), A typology of Innovations in Service Firms, Conference on "Managing Innovations in Services", Cardiff Business School, April 57. 


\begin{tabular}{|l|l|l|l|l|l|}
\hline $\begin{array}{c}\text { Phase of the } \\
\text { cycle }\end{array}$ & $\begin{array}{c}\text { Main forms of } \\
\text { innovation }\end{array}$ & Competitive effort & $\begin{array}{c}\text { Enabling } \\
\text { technologies }\end{array}$ & \multicolumn{1}{|c|}{$\begin{array}{c}\text { Examples } \\
\text { Impact of } \\
\text { advances on } \\
\text { production factors }\end{array}$} \\
\hline Phase I & $\begin{array}{l}\text { Incremental } \\
\text { process } \\
\text { innovation }\end{array}$ & $\begin{array}{l}\text { Improvement of } \\
\text { service efficiency } \\
\text { (cost decrease) }\end{array}$ & Mainframe & $\begin{array}{l}\text { The } \\
\text { computerisation } \\
\text { of insurance } \\
\text { policy records, } \\
\text { personnel records } \\
\text { and payrolls }\end{array}$ & $\begin{array}{l}\text { Labour-saving } \\
\text { technical } \\
\text { advances which } \\
\text { increase the } \\
\text { amount of capital } \\
\text { used }\end{array}$ \\
\hline Phase II & $\begin{array}{l}\text { Radical process } \\
\text { innovation }\end{array}$ & $\begin{array}{l}\text { Improvement of } \\
\text { service quality }\end{array}$ & $\begin{array}{l}\text { Mini and micro } \\
\text { computers } \\
\text { management of } \\
\text { housing waiting } \\
\text { lists in local public } \\
\text { administration, } \\
\text { on-line insurance } \\
\text { policy quotations, } \\
\text { ATMs }\end{array}$ & $\begin{array}{l}\text { Technical } \\
\text { advances which } \\
\text { are neutral in } \\
\text { terms of labour, } \\
\text { and which } \\
\text { encourage an } \\
\text { increase in the } \\
\text { quantity and } \\
\text { particularly the } \\
\text { quality and variety } \\
\text { of capital }\end{array}$ \\
\hline Phase III & $\begin{array}{l}\text { Product } \\
\text { innovation }\end{array}$ & New services & Networks & $\begin{array}{l}\text { Technical } \\
\text { advances which } \\
\text { save capital whilst } \\
\text { improving its } \\
\text { quality }\end{array}$ \\
\hline
\end{tabular}

Table 1: The main characteristics of the reverse cycle 


\begin{tabular}{|c|c|c|c|}
\hline TYPES OF INNOVATION & \multicolumn{2}{|c|}{ SUB-CATEGORIES } & DEFINITION \\
\hline \multirow{5}{*}{$\begin{array}{l}\text { A: PRODUCT/SERVICE } \\
\text { INNOVATIONS }\end{array}$} & \multicolumn{2}{|c|}{ A1: "Absolute" product/service innovations } & $\begin{array}{l}\text { New service, concept or policy for the } \\
\text { whole market }\end{array}$ \\
\hline & \multicolumn{2}{|c|}{ A2: "Relative" product/service innovations } & $\begin{array}{l}\text { New service, concept or policy for the } \\
\text { company concerned }\end{array}$ \\
\hline & \multirow[t]{3}{*}{$\begin{array}{l}\text { A3:Tailor-made products/services } \\
\text { innovations }\end{array}$} & $\begin{array}{l}\text { 1) Adaptive tailor- } \\
\text { made innovations }\end{array}$ & $\begin{array}{l}\text { Adaptation of a standard policy for a } \\
\text { particular client through changes in } \\
\text { pricing or the addition of certain } \\
\text { supplementary clauses }\end{array}$ \\
\hline & & $\begin{array}{l}\text { 2) Fully tailor-made } \\
\text { innovations }\end{array}$ & $\begin{array}{l}\text { Design of a genuinely specific policy for } \\
\text { a given client }\end{array}$ \\
\hline & & $\begin{array}{l}\text { 3) Cover for special } \\
\text { risks }\end{array}$ & $\begin{array}{l}\text { Cover for a new risk affecting only small } \\
\text { populations. }\end{array}$ \\
\hline \multirow[b]{2}{*}{$\begin{array}{l}\text { B: ARCHITECTURAL } \\
\text { INNOVATIONS }\end{array}$} & \multicolumn{2}{|c|}{ B1: Product/service bundling innovations } & $\begin{array}{lll}\begin{array}{l}\text { Recombination } \\
\text { products/services }\end{array} & \text { of } & \text { existing } \\
\end{array}$ \\
\hline & \multicolumn{2}{|c|}{ B2: Product/service unbundling innovations } & $\begin{array}{l}\text { Isolation of one element in a } \\
\text { product/service for sale as a separate } \\
\text { item. }\end{array}$ \\
\hline \multicolumn{3}{|c|}{ C: INNOVATIONS BASED ON MODIFICATIONS TO A PRODUCT OR SERVICE } & $\begin{array}{l}\text { Certain specifications and options are } \\
\text { modified, leaving the basic formula } \\
\text { unchanged }\end{array}$ \\
\hline \multirow{5}{*}{$\begin{array}{l}\text { D: PROCESS } \\
\text { ORGANISATIONAL AND } \\
\text { INNOVATIONS, INNOVATIONS } \\
\text { IN METHODS AND } \\
\text { MANAGEMENT }\end{array}$} & \multicolumn{2}{|c|}{$\begin{array}{l}\text { D1: Innovations introduced in support of product/service } \\
\text { innovations }\end{array}$} & $\begin{array}{l}\text { Process and organisational innovation } \\
\text { following a product/service of type } A, B \\
\text { or } C \text { and indissociable from it }\end{array}$ \\
\hline & \multicolumn{2}{|c|}{$\begin{array}{l}\text { D2: innovations associated with a product/service that } \\
\text { remains unchanged in terms of both formal specifications } \\
\text { and mode of delivery }\end{array}$} & $\begin{array}{l}\text { Significant change in process } \\
\text { (technology, work organisation), leaving } \\
\text { the final service unchanged }\end{array}$ \\
\hline & \multicolumn{2}{|c|}{$\begin{array}{l}\text { D3: innovations associated with a product/service whose } \\
\text { formal specifications remain unchanged but whose mode of } \\
\text { delivery, perceived quality and marketing are to be improved }\end{array}$} & $\begin{array}{l}\text { Significant change in process } \\
\text { (technology, work organisation) leaving } \\
\text { the product "formally" identical but } \\
\text { improved in quality }\end{array}$ \\
\hline & \multicolumn{2}{|l|}{ D4: Formal management innovations } & $\begin{array}{l}\text { Innovations relating to financial, } \\
\text { actuarial, legal, HR management. }\end{array}$ \\
\hline & \multicolumn{2}{|c|}{$\begin{array}{l}\text { D5: Informal management innovations (ad hoc or makeshift } \\
\text { innovation) }\end{array}$} & $\begin{array}{l}\text { Differentiated from the forms outlined } \\
\text { above by their informal nature. }\end{array}$ \\
\hline
\end{tabular}

Table 2: The main forms of innovation in insurance services 